\title{
Universiteit
}

Leiden

The Netherlands

\section{Public land in the Roman Republic : a social and economic history of the ager publicus}

Roselaar, S.T.

\section{Citation}

Roselaar, S. T. (2009, January 14). Public land in the Roman Republic : a social and economic history of the ager publicus. Retrieved from https://hdl.handle.net/1887/13401

Version: $\quad$ Not Applicable (or Unknown)

License: $\quad$ Licence agreement concerning inclusion of doctoral thesis in the Institutional Repository of the University of Leiden

Downloaded from: https://hdl.handle.net/1887/13401

Note: To cite this publication please use the final published version (if applicable). 


\section{CURRICULUM VITAE}

Saskia Tessa Roselaar werd geboren op 5 januari 1980 te Alkmaar. In 1998 behaalde zij haar VWO-diploma aan het Murmellius Gymnasium te Alkmaar. In 2004 studeerde zij af 'met zeer veel genoegen' in de Geschiedenis van de Oudheid en Antieke Cultuur aan de Universiteit Utrecht. Vanaf september 2004 werd zij aangesteld als assistent in opleiding aan de Universiteit Leiden, waar zij haar proefschrift in augustus 2008 voltooide. 